\title{
Population dynamics of the predator
} Alloeocranum biannulipes Montrouzier and Signoret (Hemiptera: Reduviidae) feeding on the larger grain borer, Prostephanus truncatus (Horn) (Coleoptera: Bostrichidae),
infesting cassava chips

Yêyinou Laura Estelle Loko ${ }^{1 *}$, Alexis Onzo ${ }^{2}$, Benjamin Datinon ${ }^{3}$, Lopez Akogninou ${ }^{2}$, Joelle Toffa ${ }^{1}$, Elie Dannon ${ }^{3}$ and Manuele Tamo ${ }^{3}$

\begin{abstract}
Functional and numerical responses of adult females of the predatory bug Alloeocranum biannulipes Montrouzier and Signoret (Hemiptera: Reduviidae) to density changes of the larger grain borer, Prostephanus truncatus (Horn) (Coleoptera: Bostrichidae), infesting cassava chips were investigated under laboratory conditions. Starved predators were exposed to different prey density as treatments with 6 replicates. Numbers of prey consumed, eggs laid, and adults emerged as well as the hatching rates were recorded daily. When feeding on the larvae of $P$. truncatus, consumption increased linearly $\left(R^{2}=0.858\right)$ with the increase in larval density. At the highest pupal density of 6 P. truncatus pupae per predator, A. biannulipes adult showed the highest consumption rates (1.67 pupae). The Holling's type I and III functional responses were observed when A. biannulipes consumed $P$. truncatus larvae and pupae, respectively. The attack of the predator estimated to $0.027 \mathrm{~h}^{-1}$ for larvae and $0.125 \mathrm{~h}^{-1}$ for pupae. The handling time spent on pupae by the adult predator was $0.352 \mathrm{~h}$ with a theoretical daily maximum predation $\left(T / T_{\mathrm{h}}\right)$ of 68.18 pupae of $P$. truncatus. The numerical response of $A$. biannulipes was positively linked to pupal density, with more eggs laid per female, and higher hatching rate when exposed to higher prey densities. Efficiency of food conversion into eggs by A. biannulipes increased with decreasing larval densities and remained constant with increasing pupal densities. These functional and numerical responses exhibited by $A$. biannulipes suggest that this predator can effectively control $P$. truncatus larvae at low densities and pupae both at low and high densities. Therefore, A. biannulipes could be a good candidate for the biological control of $P$. truncatus.
\end{abstract}

Keywords: Alloeocranum biannulipes, Prostephanus truncatus, pest of cassava chips, Predator/prey interactions, Reproductive capacity

\footnotetext{
* Correspondence: lokoestelle@yahoo.fr

'Laboratory of Applied Entomology (LEnA), Faculty of Sciences and Technology of Dassa, National University of Sciences, Technologies, Engineering and Mathematics of Abomey, BP 14 Dassa, Benin Full list of author information is available at the end of the article
}

(c) The Author(s). 2020 Open Access This article is licensed under a Creative Commons Attribution 4.0 International License, which permits use, sharing, adaptation, distribution and reproduction in any medium or format, as long as you give appropriate credit to the original author(s) and the source, provide a link to the Creative Commons licence, and indicate if changes were made. The images or other third party material in this article are included in the article's Creative Commons licence, unless indicated otherwise in a credit line to the material. If material is not included in the article's Creative Commons licence and your intended use is not permitted by statutory regulation or exceeds the permitted use, you will need to obtain permission directly from the copyright holder. To view a copy of this licence, visit http://creativecommons.org/licenses/by/4.0/. 


\section{Background}

Cassava, Manihot esculenta Crantz, is the fifth root crop in the world and considered the most important food crop behind maize, rice, wheat, and potatoes (FAO, 2017). Cassava plays a major role in the food security of the poorest people in Africa, who produce more than half of the world cassava production (FAO, 2017). In sub-Saharan Africa, cassava is cultivated under a wide range of ecological and agronomic conditions due to its adaptability to relatively marginal soils and erratic rainfall conditions and to its high productivity per unit of land and labor (Spencer and Ezedinma, 2017). Its roots are rich in calories, and its leaves are a good source of protein and minerals (Burns et al. 2012). In Benin, cassava is one of the main priority crops identified by the government for the development of the agricultural sector. This speculation is of great importance in the diet of people in Benin, where its production is estimated at 4, 341,848 tonnes in 2017 (FAO, 2017). In Benin, cassava is consumed under various forms and therefore has become a commodity crop by marketing many its derivatives, thereby contributing to poverty reduction (Hongbété et al. 2011).

However, despite its nutritional and economic importance, the cultivation of cassava in Benin remains subject to many abiotic and biotic constraints (Agre et al. 2015). The high perishability of fresh cassava roots remains the main constraint for their post-harvest use (Chijindu and Boateng, 2008) and accounts among the main reasons for the loss of diversity in Benin (Agre et al. 2015). Indeed, after harvest, cassava roots cannot be stored for more than 4 days because of post-harvest physiological deterioration (Buschmann et al. 2000). To overcome these constraints, harvested cassava roots are traditionally processed into many derivatives including chips. Unfortunately, cassava chips are often severely attacked by some stored product insects that can reduce whole stocks of chips into powder in a few months, thereby rendering it unfit for human consumption and sale (Chijindu and Boateng, 2008). Among the diversity of insect pests of stored cassava chips, the larger grain borer Protephanus truncatus (Horn) (Coleoptera: Bostrichidae) is the most widespread in Benin and the most important in terms of damage caused (Gnonlonfin et al. 2008). Losses due to $P$. truncatus are significant and can reach 40 to $50 \%$ of stored cassava chips after just 3 months of storage (Hell et al. 2006). To preserve stored cassava chips, farmers usually use synthetic insecticides that apply to cotton (Hell et al. 2006). As a result, farmers and consumers are often poisoned, leading to death as reported by Ton et al. (2000). It urges, therefore, to seek/for alternative control methods that preserve the environment and protect farmers' and consumers' health.
Biological control through the use of predators is widely recognized as an effective control method for regulating insect pest populations (Eneh, 2011). Since $P$. truncatus is an exotic invasive pest originating from Latin America, there have been attempts in West Africa to introduce biological control agents from the area of origin, notably the predator Teretrius nigrescens Lewis (Borgemeister et al. 2003). However, the introduced predator seemed to be more adapted to forest habitats than storage structures and thus was subsequently unable to disperse and control $P$. truncatus by itself (Borgemeister et al. 1997), unless used in augmentative releases (Hell et al. 2006). A biological control agent of $P$. truncatus better adapted to storage structures may well be the generalist predator Alloeocranum biannulipes Montrouzier and Signoret (Hemiptera: Reduviidae). Several studies have shown that $A$. biannulipes is an important predator of stored commodity insect pests such as Dinoderus porcellus Lesne (Loko et al. 2017) and Tribolium confusum du Val (Awadallah et al. 1984) that also occur in stored cassava chips (Schäfer et al. 2000; Gnonlonfin et al. 2008). It would therefore be interesting to evaluate the potential of $A$. biannulipes as a biological control agent for $P$. truncatus. One such evaluation could be through the study of its functional and numerical responses (Lester and Harmsen, 2002; Rahman et al. 2012) to $P$. truncatus populations in cassava chips. Indeed, functional and numerical responses are used to determine whether a predator can be a good biocontrol agent. The functional response of a predator describes the relationship between the numbers of prey attacked at different prey densities, while the numerical response is defined as the change in the reproductive capacity of a predator at different densities of the prey (Rahman et al. 2012).

The present study aimed, therefore, at provide such quantitative information on the ability of $A$. biannulipes to control $P$. truncatus in stored cassava chips in Benin. The results herein may assist to develop an integrated pest management, IPM, program to control P. truncatus larvae, and pupae in infected cassava chips.

\section{Materials and methods}

\section{Rearing technique}

Adults of the prey pest, $P$. truncatus, were obtained from samples of cassava chips collected in farmers' storage structures at Lamougo village in the Municipality of Dassa-Zoumé (latitude $7^{\circ} 41^{\prime} 33^{\prime \prime} \mathrm{N}$ and longitude $2^{\circ}$ $13^{\prime} 25^{\prime \prime}$ E), Benin. The collected adult insects were raised in one-ended plastic boxes $\left(9.5 \times 6.5 \mathrm{~cm}^{2}\right.$, height per diameter) containing sterilized cassava chips. The open-end of the rearing plastic boxes was covered with muslin and held in place by elastic strings to allow adequate ventilation and prevent the insects from escaping. 
The plastic boxes containing the insects were shelved in the laboratory under ambient conditions at $25 \pm 2{ }^{\circ} \mathrm{C}$, 45-65\% RH, and 12L:12D cycle. After 7 days, the parent-adult $P$. truncatus was removed from the rearing boxes, and newly emerged adults were collected to be used in the bioassay study.

Adults of the predator A. biannulipes were collected from stored rice at Magoumi (latitude $8^{\circ} 10^{\prime} 26^{\prime \prime} \mathrm{N}$ and longitude $2^{\circ} 13^{\prime} 59^{\prime \prime} \mathrm{E}$ ), a village in the Municipality of Glazoué, Benin. They were reared in experimental plastic boxes $\left(9.5 \times 6.5 \mathrm{~cm}^{2}\right.$ height per diameter $)$ containing cassava chips infested with $P$. truncatus. Five hundred grams of cassava chips was placed in each plastic box in which 100 adult $P$. truncatus of undetermined age and sex were transferred. Two weeks later, 10 adults $A$. biannulipes of undetermined age and sex were added to plastic boxes containing the infested cassava chips. Every 2 weeks thereafter, adult female predators were removed from the rearing boxes and used in the experiments.

\section{Functional response of $A$. biannulipes to $P$. truncatus}

Evaluation of the functional response of the predator $A$. biannulipes feeding on larvae and pupae of $P$. truncatus was made according to the methodology described by Loko et al. (2017). The larvae and pupae of P. truncatus were collected by breaking infested cassava chips with a handheld mortar and placed in plastic boxes $(3.5 \mathrm{~cm}$ diameter $\times 3 \mathrm{~cm}$ height). Adults of both sexes of the predator (2-4 days old) were starved for $24 \mathrm{~h}$ (Sing and Arbogast, 2008; Rahman et al. 2009) and transferred individually into plastic boxes, where $P$. truncatus larvae or pupae have been introduced $2 \mathrm{~h}$ ago, (Atlihan et al. 2010). Plastic boxes used for the control treatment were maintained without any predators to record the natural mortality of $P$. truncatus. Experiments were conducted with $P$. truncatus at various densities, i.e., 1, 2, 4, 6, 8, and 10 for larvae (Rahman et al. 2009; Farhadi et al. 2015) and 1, 2, 3, 4, 5, and 6 for pupae (Rahman et al. 2009; Sahayaraj et al. 2015). The experiment was repeated 6 times for each prey density. After $24 \mathrm{~h}$, the number of prey killed by the predator was recorded daily for 7 consecutive days, while replacing prey killed at the target density (Rahman et al. 2009).

\section{Numerical response of $A$. biannulipes to $P$. truncatus}

The numerical response of $A$. biannulipes to $P$. truncatus larvae or pupae was evaluated according to the methodology described by Sabaghi et al. (2011), with slight modifications. Five females of $A$. biannulipes (2-4 days old) were individually paired with an adult male in Petri dishes ( $9 \mathrm{~cm}$ diameter $\times 2 \mathrm{~cm}$ height) to allow mating (Omkar and Pervez, 2004). The ejection of spermatophore capsules by mated females confirmed successful copulation (Ambrose et al. 2009). After mating, the females were isolated in Petri dishes and starved for $24 \mathrm{~h}$. Subsequently, they were exposed to 6 different densities of $P$. truncatus larvae $(1,2,4,6,8$, and 10) and of pupae (1, 2, 3, 4, 5, and 6) (Rahman et al. 2009). After $24 \mathrm{~h}$, the females were removed from the Petri dishes, and the number of eggs laid and prey consumed were recorded. Observations were made for 7 consecutive days with the same prey densities (Rahman et al. 2012). The number of replicates was 6 at each prey density.

\section{Data analysis}

To determine the type of functional response exhibited by $A$. biannulipes to $P$. truncatus, the data were analyzed in 2 steps as suggested by Allahyari et al. (2004) and using the SAS 9.3 Analysis Software (SAS, 2009). In a first step, a logistic regression of the proportion of $P$. truncatus larvae or pupae killed $\left(N_{a} / N_{0}\right)$ as a function of initial density $\left(N_{0}\right)$ was used to determine the type of response of $A$. biannulipes. For this purpose, the cubic model in the logistic regression analysis was used (Juliano, 2001; Xue et al. 2009; Butt and Xaaceph, 2015), according to the following formula:

$$
\frac{N_{a}}{N_{0}}=\frac{\exp \left(P_{0}+P_{1} N_{0}+P_{2} N_{0}^{2}+P_{3} N_{0}^{3}\right)}{\left[1+\exp \left(P_{0}+P_{1} N_{0}+P_{2} N_{0}^{2}+P_{3} N_{0}^{3}\right]\right.}
$$

where $P_{0}, P_{1}, P_{2}$, and $P_{3}$ are the constants of linear, quadratic, and cubic coefficients, respectively. A value of $P_{1}$ that does not differ significantly from zero indicates type I functional response (Juliano, 2001). A significant negative $P_{1}$ value describes type II functional response, while a positive $P_{1}$ value describes a type III functional response (Butt and Xaaceph, 2015).

The second step consisted of modeling the relationship between the number of prey consumed $\left(N_{a}\right)$ and the initial prey density $\left(N_{0}\right)$ in order to estimate the instantaneous searching time or attack rate $(a)$ and the handling time $\left(T_{\mathrm{h}}\right)$. Estimations of these two parameters of a functional response were made using the Holling (1959) type I model and the type III model of Hassell et al. (1977):

- Type I functional response $N_{a}=a T N_{0}$

- Type III functional response $N_{a}=N_{0}\{1$ $\left.\exp \left[-a\left(T-T_{h} N_{0}\right)\right]\right\}$

where $a$ is the instantaneous search time or attack rate, $T_{\mathrm{h}}$ is the handling time by prey density, $T$ is the total exposure time of $P$. truncatus larvae or pupae (24 h), $N_{a}$ represents the number of prey consumed, and $N_{0}$ is the initial prey density. 
Table 1 Mean number of $P$. truncatus larvae killed in $24 \mathrm{~h}$ by $A$. biannulipes in function of density

\begin{tabular}{llll}
\hline $\begin{array}{l}\text { Prey } \\
\text { density }\end{array}$ & $\begin{array}{l}\text { Number of } \\
\text { prey killed } \\
\text { Mean } \pm \text { S.E. }\end{array}$ & $\begin{array}{l}\text { Number of } \\
\text { observations }\end{array}$ & ANOVA \\
\hline 1 & $0.02 \pm 0.12 \mathrm{a}$ & 60 & $\mathrm{df}=359$ \\
2 & $0.05 \pm 0.22 \mathrm{a}$ & 60 & $\mathrm{~F}=4.418$ \\
4 & $0.15 \pm 0.57 \mathrm{ab}$ & 60 & $P<0.001$ \\
6 & $0.25 \pm 0.50 \mathrm{~b}$ & 60 & \\
8 & $0.32 \pm 0.65 \mathrm{~b}$ & 60 & \\
10 & $0.13 \pm 0.38 \mathrm{ab}$ & 60 & \\
\hline
\end{tabular}

Mean values followed by different letters within each column differ significantly $(P<0.05)$

Nonlinear regression was performed to estimate the parameters $a$ and $T_{\mathrm{h}}$ (Xue et al. 2009). For this, the values of $a$ and $T_{h}$ required by the nonlinear regression method were found by linear regression of $N_{a} / N_{0}$. The resulting intercept is the initial estimate of $T_{\mathrm{h}}$, and conversely the regression coefficient (slope) is an estimate of $a$ (Livdahl and Stiven, 1983). These first estimates were refined by the NLR method.

Variation in the number of prey killed by the predator with density was assessed by ANOVA using the IBM SPSS 25 statistical analysis software. The data submitted to ANOVA were log-transformed before by hand to ensure the homogenization of the variances. Significant differences between the means were separated using the Student Newman Keuls test $(P \leq 0.05)$.

The efficiency of conversion of ingested feed (ECI) to egg biomass at different prey densities was calculated using the following formula described by Omkar and Pervez (2004):
Table 2 Mean number of $P$. truncatus pupae killed in $24 \mathrm{~h}$ by the predator $A$. biannulipes in function of density

\begin{tabular}{llll}
\hline $\begin{array}{l}\text { Prey } \\
\text { density }\end{array}$ & $\begin{array}{l}\text { Mean number } \\
\text { of prey killed } \\
\text { Mean } \pm \text { S.E. }\end{array}$ & $\begin{array}{l}\text { Number of } \\
\text { observation }\end{array}$ & ANOVA \\
\hline 1 & $0.10 \pm 0.30 \mathrm{a}$ & 60 & $\mathrm{df}=359$ \\
2 & $0.27 \pm 0.57 \mathrm{a}$ & 60 & $\mathrm{~F}=1.205$ \\
3 & $0.38 \pm 0.84 \mathrm{a}$ & 60 & $P>0.05$ \\
4 & $0.38 \pm 0.90 \mathrm{a}$ & 60 & \\
5 & $0.43 \pm 1.09 \mathrm{a}$ & 60 & \\
6 & $0.58 \pm 1.45 \mathrm{a}$ & 60 & \\
\hline
\end{tabular}

Mean values followed by different letters within each column differ significantly $(P<0.05)$

$$
\mathrm{ECI}=\frac{\text { Number of eggs laid }}{\text { Number of prey consumed }} \times 100
$$

Data on oviposition and ECI by A. biannulipes at different prey densities were fitted using regression analysis to determine the relationship between oviposition and prey density and ECI and prey density.

\section{Results and discussion}

Functional response of $A$. biannulipes to $P$. truncatus

The predator $A$. biannulipes feed on P. truncatus larvae and pupae as well as on other stored products insect pests such as Dinoderus porcellus (Loko et al. 2017), Tribolium confusum, Corcyra cephalonica, and Anagasta kuehniella (Awadallah et al. 1984). Predation on P. truncatus larvae by $A$. biannulipes differed significantly among larval prey densities (Table 1). Though the predation gradually increased along with the increase in prey

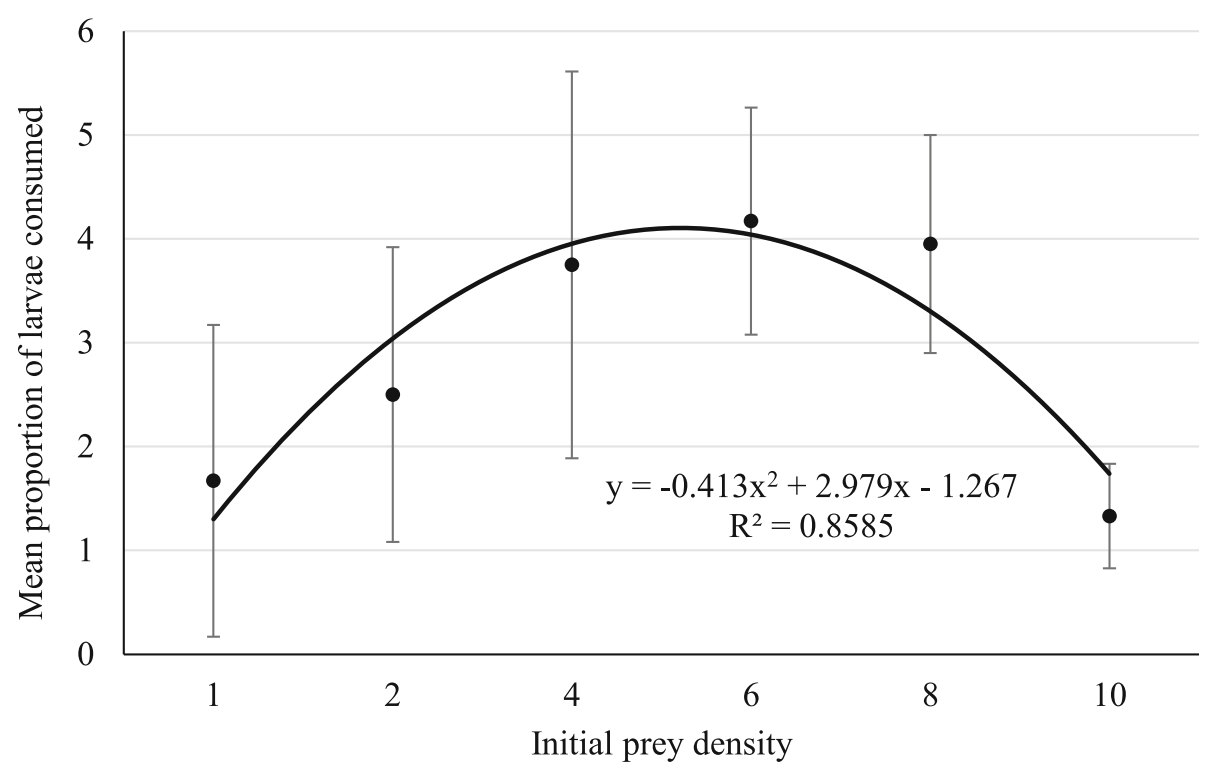

Fig. 1 Mean proportion of $P$. truncatus larvae consumed by A. biannulipes at six different densities 


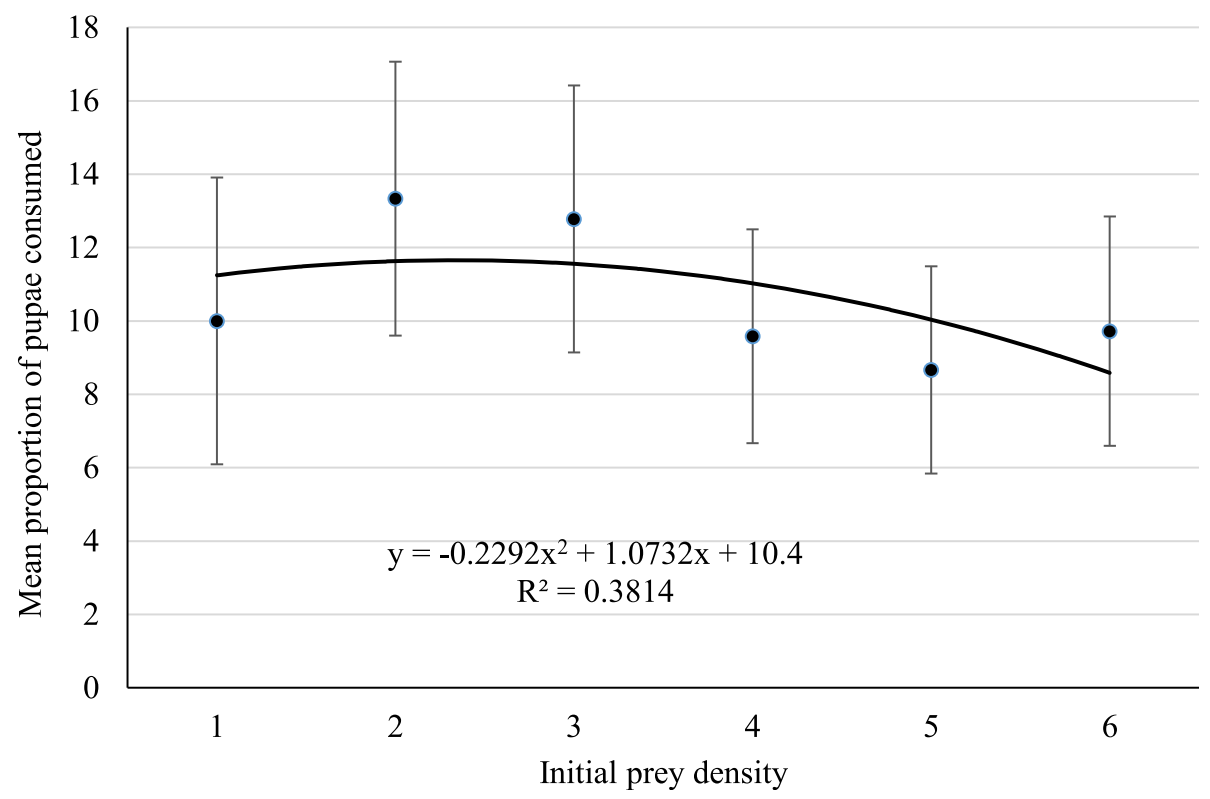

Fig. 2 Mean proportion of $P$. truncatus pupae consumed by A. biannulipes at six different densities

density, it decreased beyond the density of 8 (Table 1 ). The relationship between the percentage of larvae consumed by $A$. biannulipes and the different larval densities offered was expressed by a polynomial equation with a regression coefficient of $R^{2}=0.858$ (Fig. 1). Functional response of $A$. biannulipes to $P$. truncatus larvae fitted a Holling's type I functional response (Table 3). The adults $A$. biannulipes consume a constant proportion of $P$. truncatus larvae with larval densities increasing until the predator's killing ability is saturated (Ofuya and Akingbohungbe, 1988). Indeed, although the sign of the linear term was negative, it was non-significant $(P>0.05)$. A type I functional response was also exhibited by other Hemipterans such as Orius insidiosus and Nabis capsiformis fed on bollworm eggs (Parajulee et al. 2006). This type I functional response exhibited by $A$. biannulipes is surprising, however, because alike the majority of Reduviidae, when this predator feeds on $D$. porcellus larvae it had exhibited a type II functional response (Loko et al. 2017). However, the negative value of the linear $\left(P_{1}\right)$ parameter, which showed that the proportion of prey consumed declines monotonically with the initial prey density, indicated a tendency towards a type II functional response (Patel and Zhang, 2017). In fact, the transition from a type I functional response to type II can be influenced by environmental conditions, temperature and relative humidity, host plant, prey type, and density (Mohaghegh et al. 2001).

The present results report that A. biannulipes consumed more $P$. truncatus pupae than larvae. However, this was the reverse when this predator was fed on $D$. porcellus larvae and pupae (Loko et al. 2017). This

Table 3 Maximum likelihood estimates from logistic regression of the proportion of $P$. truncatus larvae and pupae eaten by $A$. biannulipes as a function of initial prey density

\begin{tabular}{|c|c|c|c|c|c|c|}
\hline Stage & Parameters & Estimates & Standard error & $t$ value & $P$ & Best-fit model \\
\hline \multirow[t]{4}{*}{ Larvae } & Intercept $\left(P_{0}\right)$ & 3.036 & 2.598 & 1.17 & 0.363 & \\
\hline & Linear $\left(P_{1}\right)$ & -3.160 & 2.157 & -1.46 & 0.280 & \\
\hline & Quadratic $\left(P_{2}\right)$ & 1.672 & 0.454 & 3.68 & 0.066 & Type I \\
\hline & Cubic $\left(P_{3}\right)$ & -0.130 & 0.027 & -4.81 & 0.040 & \\
\hline \multirow[t]{4}{*}{ Pupae } & Intercept $\left(P_{0}\right)$ & -17.000 & 4.769 & -3.56 & 0.070 & Type III \\
\hline & Linear $\left(P_{1}\right)$ & 29.638 & 5.434 & 5.45 & 0.032 & \\
\hline & Quadratic $\left(P_{2}\right)$ & -7.666 & 1.739 & -4.41 & 0.047 & \\
\hline & Cubic $\left(P_{3}\right)$ & 0.694 & 0.164 & 4.23 & 0.051 & \\
\hline
\end{tabular}


Table 4 Estimated values for A. biannulipes feeding on P. truncatus larvae and pupae

\begin{tabular}{|c|c|c|c|c|c|c|c|}
\hline & \multirow[t]{2}{*}{ Parameters } & \multirow[t]{2}{*}{ Type } & \multirow[t]{2}{*}{ Estimation } & \multirow{2}{*}{$\begin{array}{l}\text { Standard } \\
\text { error }\end{array}$} & \multicolumn{2}{|c|}{$95 \%$ confidence intervals } & \multirow[t]{2}{*}{$R^{2}$} \\
\hline & & & & & Lower & Upper & \\
\hline Larvae & $a\left(h^{-1}\right)$ & I & 0.027 & 0.010 & 0.007 & 0.048 & 0.10 \\
\hline \multirow[t]{2}{*}{ Pupae } & $a\left(h^{-1}\right)$ & III & 0.125 & 0.031 & 0.064 & 0.187 & 0.35 \\
\hline & $T_{\mathrm{h}}$ & & 0.352 & 0.097 & 2.017 & 3.722 & \\
\hline
\end{tabular}

$a$ the instantaneous search time or attack, $T_{\mathrm{h}}$ the handling time by prey density

preference for $P$. truncatus pupae could be due to its large size and high-energy content compared to larvae (Demianyk and Sinha, 1988). Indeed, Cogni et al. (2002) showed that for the predator Zelus longipes, a large prey item represented the most profitable prey in terms of energy gained. The number of $P$. truncatus pupae consumed by $A$. biannulipes did not differ significantly among prey densities (Table 2). Percentage of P. truncatus pupae consumed at varying densities was fitted using nonlinear regression of $R^{2}=0.3814$ (Fig. 2). The percentage of prey consumed was positively densitydependent, and the positive linear parameter $\left(P_{1}\right)$ and the negative quadratic parameter $\left(P_{2}\right)$ were significant, thereby indicating that the type III functional response would provide the best description of $A$. biannulipes attack on P. truncatus pupae (Table 3). This type III functional response is characterized by significantly lower proportional prey mortality at low prey densities than at high prey densities. This indicates that in a biological control program, A. biannulipes may be more effective in controlling $P$. truncatus populations with high densities of pupae. In fact, according to Holling (1965), a type III functional response allows long-term persistence of the predator, which contributes to regulating the population of their prey. A type III functional response was also observed in other reduviid bugs such as $Z$. longipes feeding on adults and nymphs of Diaphorina citri (Navarrete et al. 2014).

The estimated parameters of functional response are good indicators of the predation rate, and predatory efficiency respectively are presented in Table 4 . Handling time of A. biannulipes estimated was lower than that estimated, when fed on D. porcellus larvae (Loko et al, 2017). Moreover, it has been proven that the difference in handling time may be due to several abiotic factors that influence the time for capturing, paralyzing, killing, and digesting the prey (Cogni et al. 2002). The attack rate of $A$. biannulipes was lower when it fed on larvae than pupae of $P$. truncatus (Table 4). These attack rates of $A$. biannulipes were lower than those reported feeding on D. porcellus larvae and pupae (Loko et al. 2017).

These comparisons revealed that $A$. biannulipes could be a better biological control agent against $D$. porcellus than $P$. truncatus. In the present study, the maximum level of attack by $A$. biannulipes was estimated at 68.18 P. truncatus pupae per individual predator within a $24-\mathrm{h}$ period, giving an indication of the number of predators that have to be introduced in stored cassava chips to improve the control of this pest based on prey density.

\section{Numerical response of $A$. biannulipes to $P$. truncatus}

Oviposition by $A$. biannulipes increased with larval density, but a declining trend was noticed at higher densities (Table 5). In contrast, the number of egg hatched was $9.50 \pm 2.95$, and adult emerged were $7.33 \pm 1.36$ per female predator were higher at the lowest larval density. Although $A$. biannulipes significantly consumed more $P$. truncatus larvae with increasing of larvae density, the number of eggs laid by females, eggs hatched, and adult emerged did not significantly change among the

Table 5 Numerical response of predator A. biannulipes feeding on $P$. truncatus larvae at various densities

\begin{tabular}{|c|c|c|c|c|}
\hline \multirow{2}{*}{$\begin{array}{l}\text { Prey } \\
\text { density }\end{array}$} & \multicolumn{4}{|c|}{ Mean \pm S.E./female } \\
\hline & Prey consumed & Eggs laid & Eggs hatched & Adults \\
\hline 1 & $2.83 \pm 0.40 a$ & $25.00 \pm 3.84 a$ & $9.50 \pm 2.95 a$ & $7.33 \pm 1.36 a$ \\
\hline 2 & $4.33 \pm 0.51 b$ & $24.83 \pm 1.83 a$ & $8.00 \pm 1.54 a$ & $6.17 \pm 1.94 a$ \\
\hline 4 & $5.83 \pm 0.98 c$ & $26.83 \pm 2.78 a$ & $7.33 \pm 1.63 a$ & $4.17 \pm 1.72 \mathrm{a}$ \\
\hline 6 & $6.67 \pm 0.51 \mathrm{~cd}$ & $27.00 \pm 2.60 a$ & $8.83 \pm 1.72 \mathrm{a}$ & $6.17 \pm 0.98 a$ \\
\hline 8 & $7.50 \pm 1.04 \mathrm{de}$ & $23.83 \pm 5.11 a$ & $6.17 \pm 2.48 \mathrm{a}$ & $4.00 \pm 2.19 a$ \\
\hline 10 & $8.17 \pm 0.98 \mathrm{e}$ & $25.00 \pm 8.85 a$ & $8.00 \pm 1.67 a$ & $4.67 \pm 1.75 a$ \\
\hline ANOVA & $\begin{array}{l}\mathrm{df}=35 \\
F=52.414 \\
P<0.000\end{array}$ & $\begin{array}{l}d f=35 \\
F=0.432 \\
P>0.05\end{array}$ & $\begin{array}{l}d f=35 \\
F=2.084 \\
P>0.05\end{array}$ & $\begin{array}{l}\mathrm{df}=35 \\
F=2.576 \\
P>0.05\end{array}$ \\
\hline
\end{tabular}

In each column, mean values followed by different letters are significantly different $(P<0.05)$ 


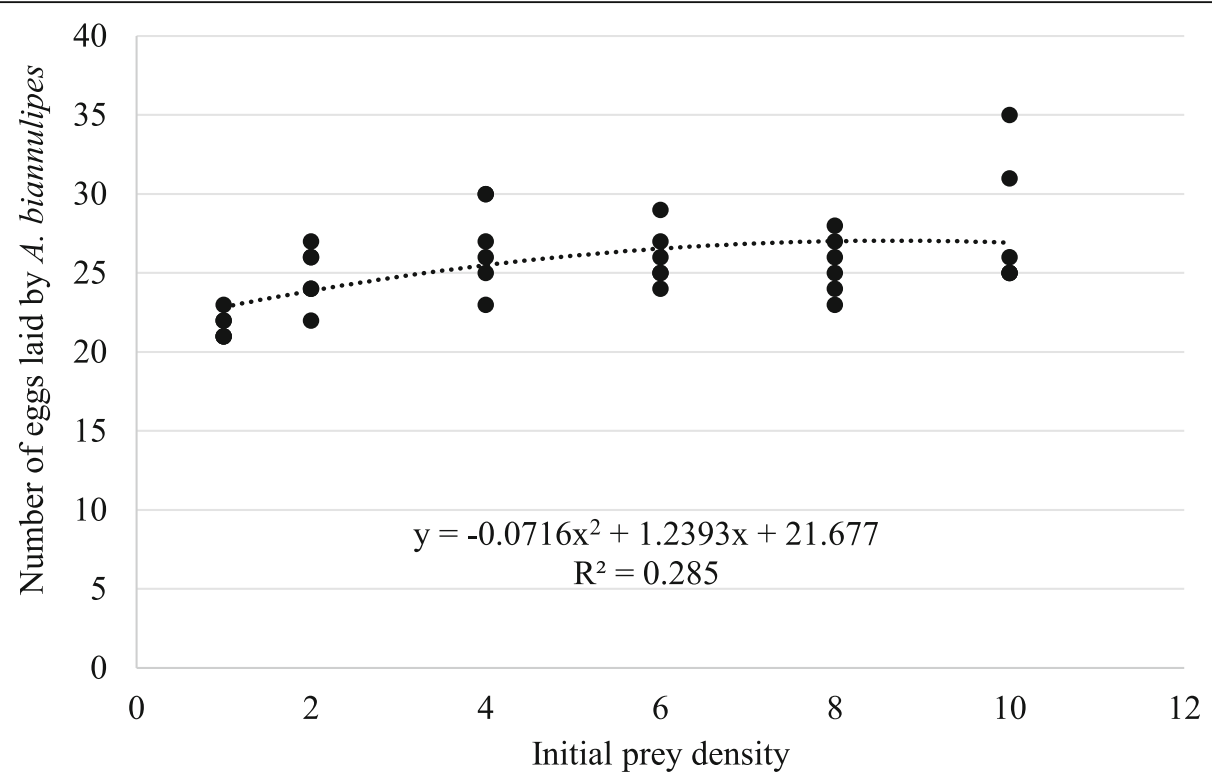

Fig. 3 Total number of eggs laid by A. biannulipes females at different densities of $P$. truncatus larvae

different larval densities (Table 5). The nonlinear regression between the total number of eggs laid by A. biannulipes female and the different densities of $P$. truncatus larvae was not significant $\left(R^{2}=0.285, P>0.05\right)$ (Fig. 3). The number of eggs laid by $A$. biannulipes feeding on $P$. truncatus larvae during $24 \mathrm{~h}$ reached its peak at the highest prey density (10 larvae/predator). The correlation coefficient between the number of $P$. truncatus larvae consumed and the number of eggs laid by $A$. biannulipes was non-significant (Fig. 4). This proves that there was no correlation between the number of P. truncatus larvae consumed and the number of eggs laid by A. biannulipes. The curve of the efficiency of food conversion into eggs by $A$. biannulipes female showed a

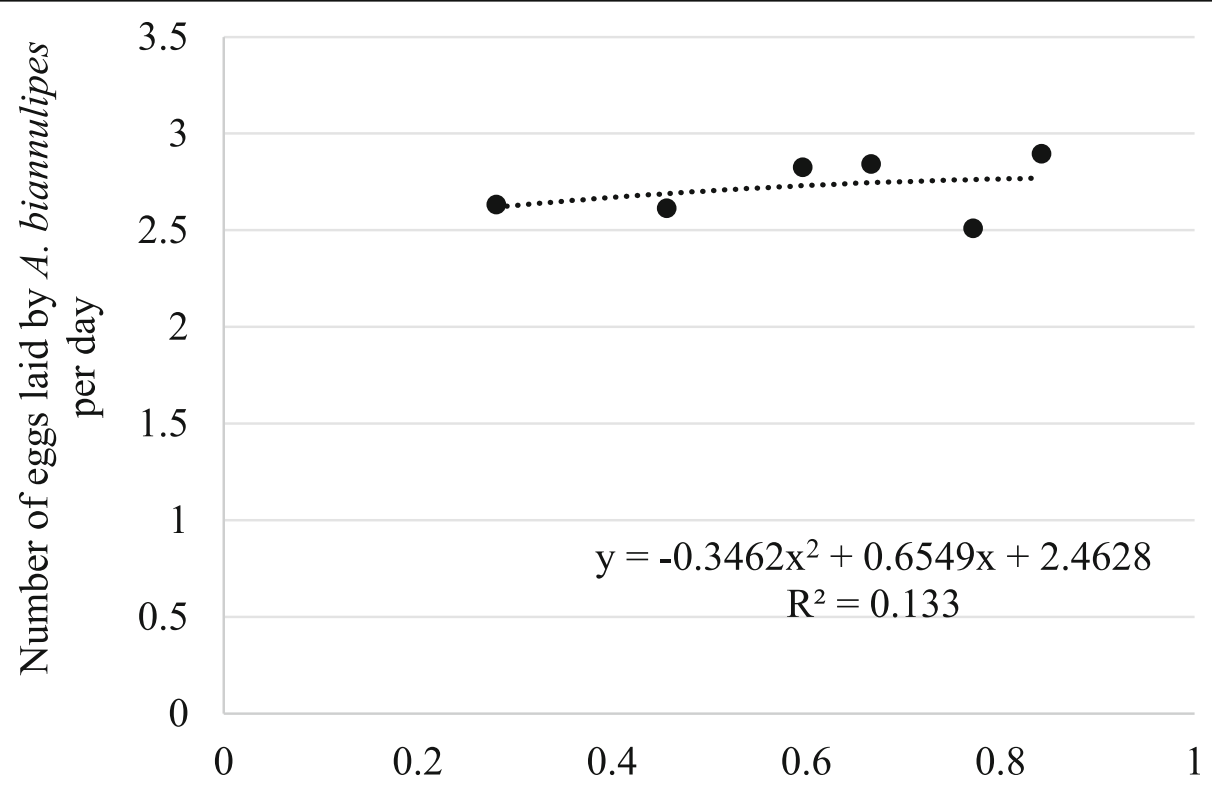

Number of $P$. truncatus larvae consumed per day

Fig. 4 Average number of eggs laid per female A. biannulipes based on P. truncatus larvae consumed 


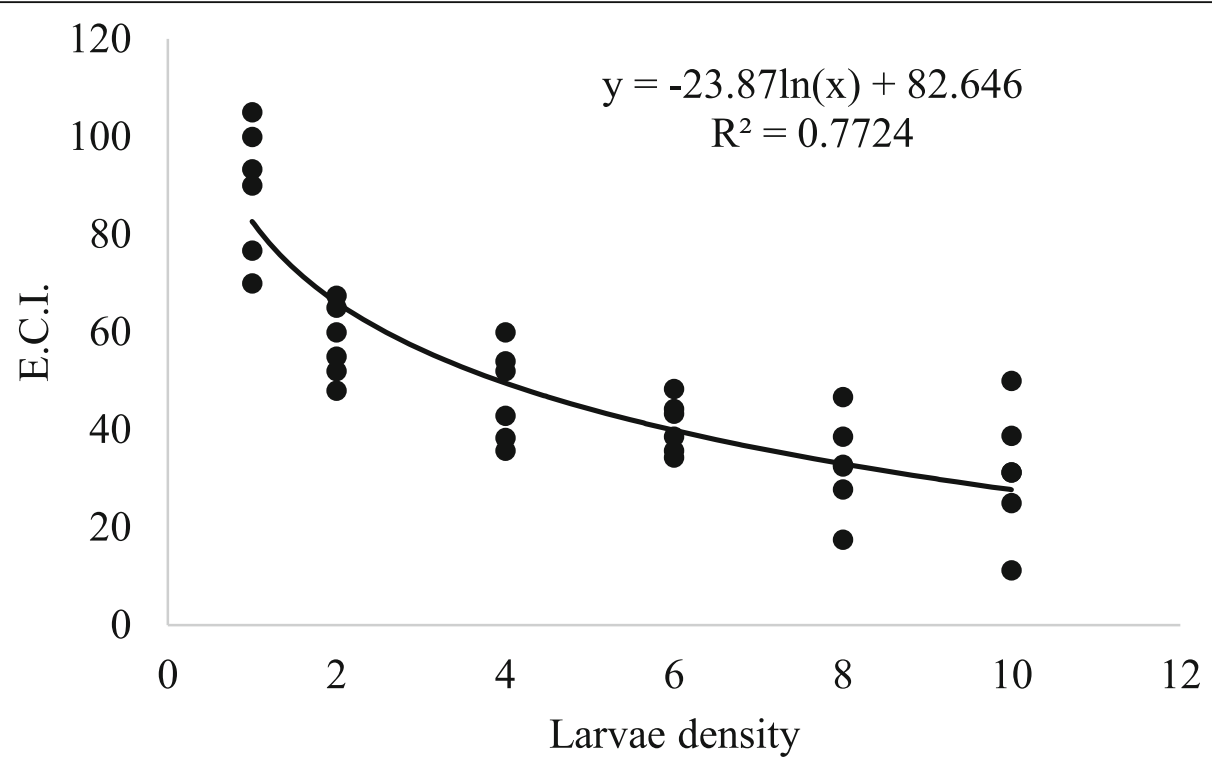

Fig. 5 Relationship between efficiency of ingested feed conversion (ECI) to egg biomass of A. biannulipes at varying densities of $P$. truncatus larvae

significantly varying trend with prey densities $(\mathrm{df}=35, F$ $=20.138, P<0.000$ ); it increased at low prey density, whereas it decreased at high density of $P$. truncatus larvae (Fig. 5). The present results showed that when $A$. biannulipes was fed on P. truncatus larvae there was a rapid and a significant increase in oviposition at low densities, but the oviposition rate declined gradually at high densities. This numerical response of $A$. biannulipes was also observed in Rhynocoris fuscipes (Ambrose and Claver, 1997). The lower numerical response at higher larval densities implies that $A$. bannulipes would be unable to keep up with the growth of a $P$. truncatus population if infestation should occur. Therefore, inoculative releases of $A$. biannulipes would be required to prevent $P$. truncatus development in the early cassava chips infestation.
The maximum number of eggs laid by $A$. biannulipes female fed on $P$. truncatus pupae was observed at the highest pupal density. The maximum number of hatched eggs and the maximum number of emerged adults per female were recorded (Table 6). It was observed that $A$. bianulipes consumed significantly more $P$. truncatus pupae with increasing of pupal density. Likewise, the number of eggs laid and eggs hatched per A. biannulipes female were density-dependant (Table 6). The densitydependent fecundity was also observed in Dicrodiplosis manihoti that fed on eggs of the mealybug Planococcus citri (Al-Zubaidy and Al-Shammari, 2017). However, the number of young $A$. biannulipes adults that emerged did not significantly differ with increasing pupal density (Table 6). The relationship between number of pupae consumed $(x)$ and number of eggs laid $(y)$ by $A$. biannulipes

Table 6 Numerical response of predator A. biannulipes feeding on $P$. truncatus pupae at various densities

\begin{tabular}{|c|c|c|c|c|}
\hline \multirow{2}{*}{$\begin{array}{l}\text { Prey } \\
\text { density }\end{array}$} & \multicolumn{4}{|c|}{ Mean \pm S.E./female } \\
\hline & Prey consumed & Eggs laid & Eggs hatched & Adults \\
\hline 1 & $0.50 \pm 0.54 a$ & $23.83 \pm 0.98 b c$ & $11.00 \pm 1.67 \mathrm{ab}$ & $9.17 \pm 2.78 \mathrm{a}$ \\
\hline 2 & $0.83 \pm 0.40 \mathrm{ab}$ & $23.33 \pm 3.01 \mathrm{abc}$ & $9.83 \pm 1.72 \mathrm{a}$ & $8.17 \pm 1.16 a$ \\
\hline 3 & $0.83 \pm 0.40 a b$ & $20.67 \pm 1.63 a$ & $11.67 \pm 2.94 a b$ & $8.50 \pm 2.58 a$ \\
\hline 4 & $1.00 \pm 0.00 a b$ & $20.50 \pm 2.25 a$ & $9.50 \pm 2.88 a$ & $7.83 \pm 1.16 a$ \\
\hline 5 & $1.00 \pm 0.00 \mathrm{ab}$ & $21.17 \pm 1.16 \mathrm{ab}$ & $11.67 \pm 2.50 \mathrm{ab}$ & $8.83 \pm 1.60 a$ \\
\hline 6 & $1.67 \pm 0.51 b$ & $24.83 \pm 2.40 c$ & $14.67 \pm 1.36 b$ & $10.33 \pm 1.50 a$ \\
\hline ANOVA & $\begin{array}{l}\mathrm{df}=35 \\
F=4.222 \\
P<0.05\end{array}$ & $\begin{array}{l}\mathrm{df}=35 \\
F=4.989 \\
P<0.05\end{array}$ & $\begin{array}{l}\mathrm{df}=35 \\
F=3.879 \\
P<0.05\end{array}$ & $\begin{array}{l}d f=35 \\
F=1.123 \\
P>0.05\end{array}$ \\
\hline
\end{tabular}

In each column, mean values followed by different letters are significantly different $(P<0.05)$ 


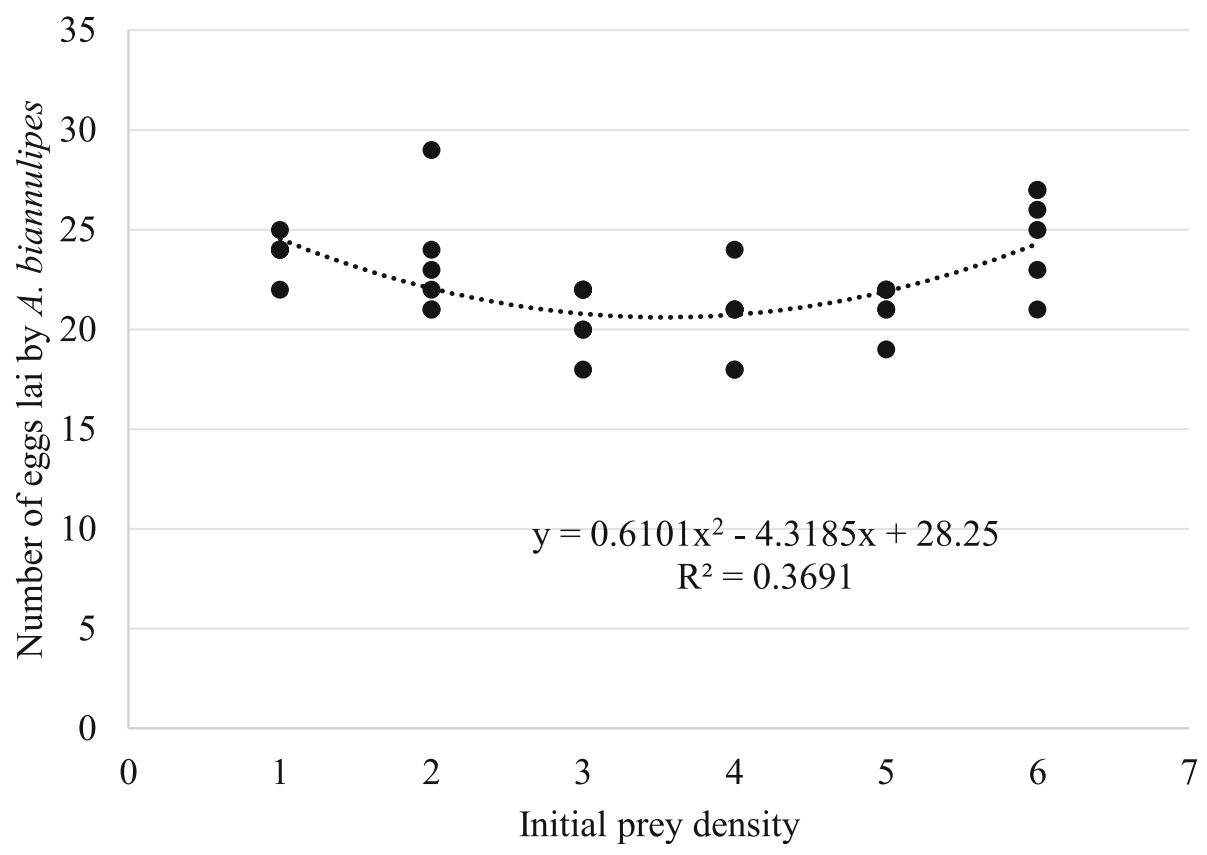

Fig. 6 Total number of eggs laid by A. biannulipes females at different densities of $P$. truncatus pupae

was nonlinear and can be represented by the regression equation presented on Fig. 6 . The average number of eggs laid per female per day was negatively correlated with the number of $P$. truncatus pupae consumed per day (Fig. 7). Moreover, the efficiency of food conversion into eggs for A. biannulipes female did not vary significantly with increasing prey density. The better digestion and assimilation of nutrients contained in P. truncatus pupae could explain the high conversion levels of ingested food into eggs by A. biannulipes (Fig. 8). In fact, it is known that ingested food conversion depends both on the predator's ability to digest and assimilate the consumed food and on

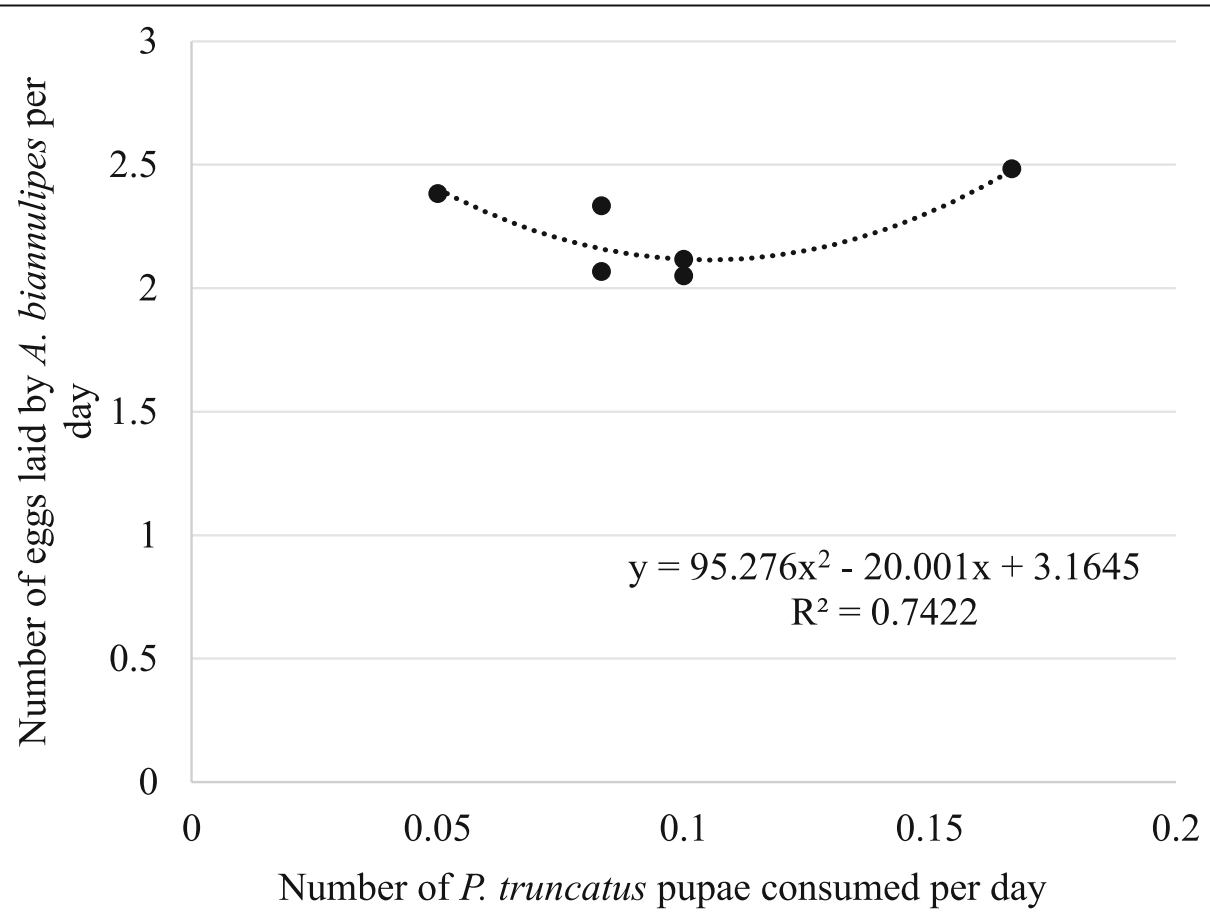

Fig. 7 Average number of eggs laid per female A. biannulipes based on P. truncatus pupae consumed per day 


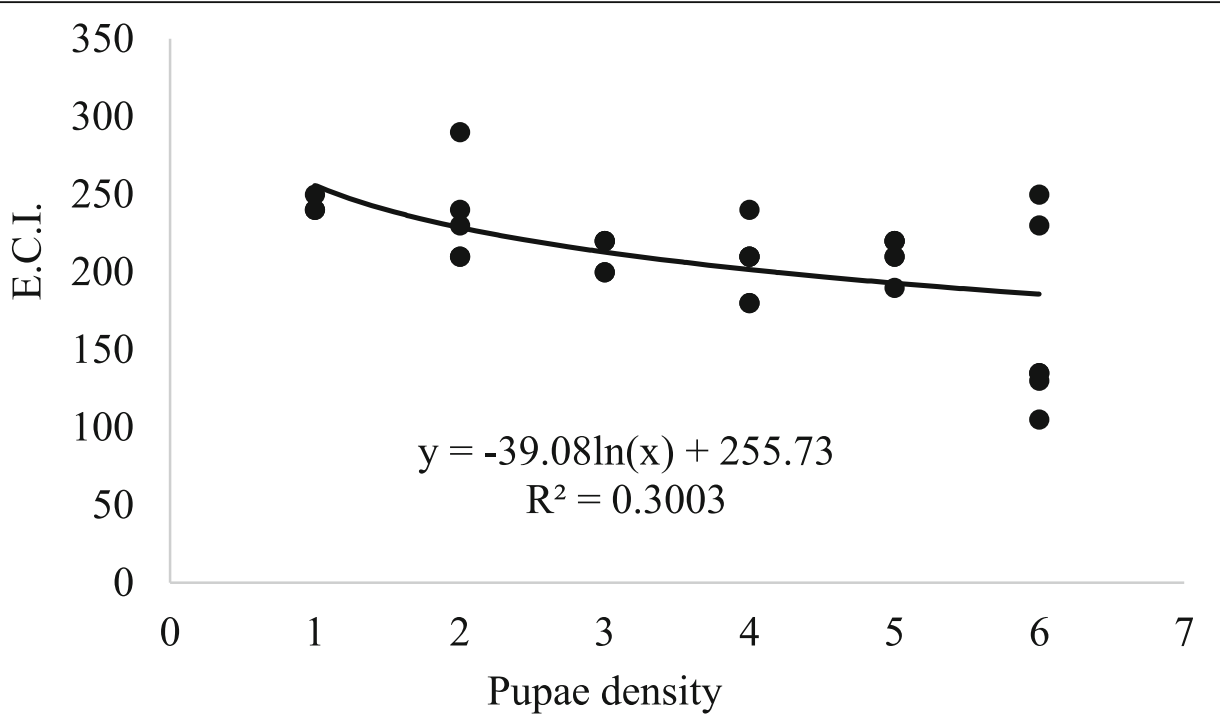

Fig. 8 Relationship between efficiency of ingested feed conversion (ECI) to egg biomass of A. biannulipes at varying densities of $P$. truncatus pupae

the allocation (maintenance, growth, reproduction) of assimilated nutrients (Hodek et al. 2012). The results showed that the functional and numerical responses of $A$. biannulipes female fed on $P$. truncatus pupae are inter-linked, in which prey biomass consumed by the predator is directly used for egg production. This also implies that $P$. truncatus pupae could be used for a longterm mass production of $A$. biannulipes.

\section{Conclusion}

A. biannulipes predation on $P$. truncatus larvae and pupae in infested cassava chips were best described by a type I and III functional responses, respectively. A. biannulipes can effectively control $P$. truncatus larvae at low densities and pupae at low and high densities. The increased $P$. truncatus pupae consumption tends to enhance the numerical response of $A$. biannulipes by enhancement of its progeny production. The obtained results conclude that $A$. biannulipes can be an efficient biological control agent of $P$. truncatus in stored cassava chips. The predator/prey interaction could be used among the control solutions of large grain borer, as it is eco-environmental friendly method. However, further studies under on-farm storage conditions are needed to evaluate the suppressive effect of $A$. biannulipes on $P$. truncatus populations.

\section{Abbreviations}

ANOVA: Analysis of variance; $R^{2}$ : Coefficient of determination; RH: Relative humidity; NLR: Nonlinear regression; P: P value; SPSS: Statistical Package for the Social Sciences

\section{Acknowledgements}

This work was supported by the Laboratory of Applied Entomology (LEnA) of the Faculty of Sciences and Technology of Dassa. The authors are grateful to Dieudonné Gavoedo for its technical assistance. We thank anonymous reviewers for their comments on previous versions of the manuscript.

\section{Authors' contributions}

LYLE conceived the research, analyzed the data, conducted the statistical analyses, wrote the manuscript, and secured the funding. AL, TJ, and DE conducted the experiments. DB contributed the material. OA and TM wrote the manuscript. The authors read and approved the manuscript.

\section{Funding}

Not applicable

\section{Availability of data and materials}

Raw and treated data generated during study are available from the corresponding author on reasonable request.

Ethics approval and consent to participate

Not applicable

\section{Consent for publication}

Not applicable

\section{Competing interests}

The authors declare that they have no competing interests.

\section{Author details}

'Laboratory of Applied Entomology (LEnA), Faculty of Sciences and Technology of Dassa, National University of Sciences, Technologies, Engineering and Mathematics of Abomey, BP 14 Dassa, Benin. ${ }^{2}$ Faculty of Agronomy, University of Parakou, BP 123 Parakou, Benin. ${ }^{3}$ International Institute of Tropical Agriculture, 08 BP 0932 Cotonou, Benin.

Received: 10 October 2019 Accepted: 20 March 2020

Published online: 01 April 2020

\section{References}

Agre AP, Kouchade S, Odjo T, Dansi M, Nzobadila B, Assogba P, Dansi A, Akoegninou A, Sanni A (2015) Diversité et évaluation participative des cultivars du manioc (Manihot esculenta Crantz) au Centre Bénin. IJBCS 9:3884080. https://doi.org/10.4314/ijbcsv9i133 
Allahyari H, Fard PA, Nozari J (2004) Effects of host on functional response of off spring in two populations of Trissolcus grandis on the Sunn pest. J Appl Entomol 128:39-43. https://doi.org/10.1046/j1439-0418200300804x

Al-Zubaidy HK, Al-Shammari HI (2017) Numerical response and efficiency of conversion of ingested food of predator Dicrodiplosis manihoti Harris, (Diptera: Cecidomyiidae) for eggs densities of mealybug Planococcus citri (Risso) (Hemiptera :Pseudococcidae). Iraqi J Agric Sci 48:496-500 http:// jcoagriuobaghdadeduiq/indexphp/intro/article/view/412

Ambrose DP, Claver MA (1997) Functional and numerical responses of the reduviid predator, Rhynocoris fuscipes $\mathrm{F}$ (Het, Reduviidae) to cotton leafworm Spodoptera litura F (Lep, Noctuidae). J Appl Entomol 121:331-336. https://doi. org/10.1111/j1439-04181997tb01415x

Ambrose DP, Rajan SJ, Nagarajan K, Krishnan SS (2009) Biology, behaviour and functional response of Sphedanolestes variabilis Distant (Insecta: Hemiptera: Reduviidae: Harpactorinae), a potential predator of lepidopteran pests. Entom Croat 13:33-44 https://hrcaksrcehr/48344

Atlıhan R, Kaydan MB, Yarımbatman A, Okut H (2010) Functional response of the coccinellid predator Adalia fasciatopunctata Revelierei to walnut aphid (Callaphis juglandis). Phytoparasitica 38:23-29. https://doi.org/10.1007/s12600009-0075-y

Awadallah KT, Tawfik MFS, Abdellah MMH (1984) Suppression effect of the reduviid predator, Allaeocranum biannulipes (Montr et Sign) on populations of some stored-product insect pests. J Appl Entomol 97:249-253. https://doi. org/10.1111/j1439-04181984tb03745x

Borgemeister C, Holst N, Hodges RJ (2003) Biological control and other pest management options for larger grain borer Prostephanus truncatus $\mathrm{In}$ : Neuenschwander, P, Borgemeister, C, Langewald, J (Eds). Biological Control in IPM Systems in Africa CABI Publishing, Wallingford, UK, pp 311-328

Borgemeister C, Meikle WG, Adda C, Degbey P, Markham RH (1997) Seasonal and meteorological factors influencing the annual flight cycle of Prostephanus truncatus (Coleoptera: Bostrichidae) and its predator Teretriosoma nigrescens (Coleoptera: Histeridae) in Benin. Bull. Entomol Res 87:239-246. https://doi. org/10.1017/S0007485300037184

Burns AE, Gleadow RM, Zacarias AM, Cuambe CE, Miller RE, Cavagnaro TR (2012) Variations in the chemical composition of cassava (Manihot esculenta Crantz) leaves and roots as affected by genotypic and environmental variation. J Agric Food Chem 60:4946-4956. https://doi.org/10.1021/jf2047288

Buschmann H, Rodriguez MX, Tohme J, Beeching JR (2000) Accumulation of hydroxycoumarins during post-harvest deterioration of tuberous roots of cassava (Manihot esculenta Crantz). Ann Bot 86:1153-1160. https://doi.org/10. 1006/anbo20001285

Butt A, Xaaceph M (2015) Functional response of Oxyopes javanus (Araneidae: Oxyopidae) to Sogatella furcifera (Hemiptera: Delphacidae) in laboratory and mesocosm. Pak J Zool 47:89-95

Chijindu EN, Boateng BA (2008) Preference of and damage to processed cassava chips by Araecerus fasciculatus (Degeer). J appl sci res 4:939-944 http:// wwwaensionlinecom/jasr/jasr/2008/939-944pdf

Cogni R, Freitas AVL, Filho ABF (2002) Influence of prey size on predation success by Zelus longipes L (Het, Reduviidae). J Appl Entomol 126:74-78. https://doi. org/10.1046/j1439-0418200200593x

Demianyk CJ, Sinha RN (1988) Bioenergetics of the larger grain borer, Prostephanus truncatus (Horn) (Coleoptera: Bostrichidae), feeding on corn. Ann Entomol Soc Am 81:449-459. https://doi.org/10.1093/aesa/813449

Eneh OC (2011) Enhancing Africa's environmental management: integrated pest management for minimizing of agricultural pesticides pollution. Res $J$ Environ Sci 5:521-529. https://doi.org/10.3923/rjes2011521529

FAO (2017) FAOSTAT database Roma: Food and Agriculture Organization. http:// www.fao.org/ Accessed 26 April 2019

Farhadi R, Allahyari H, Chi H (2015) Functional response and mutual interference of Amblyseius swirskii (Acari: Phytoseiidae) on greenhouse whitefly Trialeurodes vaporariorum on cucumber. PPS 38:37-48

Gnonlonfin GJB, Hell K, Siame AB, Fandohan P (2008) Infestation and population dynamics of insects on stored cassava and yams chips in Benin, West Africa. J Econ Entom 101:1967-1973. https://doi.org/10.1603/0022-0493-10161967

Hassell MP, Lawton JH, Beddington JR (1977) Sigmoid functional responses by invertebrate predators and parasitoids. J Anim Ecol 46:249-262. https://doi. org/10.2307/3959

Hell K, Lamboni Y, Houndekon T, Guirguissou MA (2006) Augmented release of Teretruis nigrescens Lewis (Coleoptera: Histeridae) for the control of Prostephanus truncatus (Horn) (Coleoptera: Bostrichidae) in stored cassava chips. J Stored Prod Res 42:367-376. https://doi.org/10.1016/jjspr200509001
Hodek I, van Emden HF, Honek A (2012) Ecology and behaviour of the ladybird beetles (Coccinellidae). Wiley-Blackwell, 1 edition, 600 p. https://doi.org/10. $1002 / 9781118223208$

Holling CS (1959) Some characteristics of simple types of predation and parasitism. Can Entomol 91:385-398. https://doi.org/10.4039/Ent91385-7

Holling CS (1965) The functional response of predators to prey density and its role in mimicry and population regulation. Memoirs Entomol Soc Can 97:560. https://doi.org/10.4039/entm9745fv

Hongbété F, Mestres C, Akissoé N, Pons B, Hounhouigan D, Cornet D, Nago CM (2011) Effects of cultivar and harvesting conditions (age, season) on the texture and taste of boiled cassava roots. Food Chem 126:127-133. https:// doi.org/10.1016/jfoodchem201010088

Juliano SA (2001) Nonlinear curve fitting: predation and functional response curves. In: Scheiner SM, Gurevitch J (eds) Design and analysis of ecological experiments. Oxford University Press, New York, p 432

Lester PJ, Harmsen R (2002) Functional and numerical responses do not always indicate the most effective predator for biological control: an analysis of two predators in a two-prey system. J Appl. Ecol 39:455-468. https://doi.org/10. 1046/j1365-2664200200733x

Livdahl TP, Stiven AE (1983) Statistical difficulties in the analysis of predator functional response data. Can Entomol 115:1365-1370. https://doi.org/10. 4039/Ent1151365-10

Loko YL, Djagoun AD, Dannon EA, Datinon B, Dansi A, Thomas-Odjo AA, Tamo M (2017) Functional response of the predators Alloeocranum biannulipes (Hemiptera: Reduviidae) and Teretrius nigrescens (Coleoptera: Histeridae) feeding on Dinoderus porcellus (Coleoptera: Bostrichidae) infesting yam chips. Environ Entomol 46:84-91. https://doi.org/10.1093/ee/nvw156

Mohaghegh J, De Clercq P, Tirry L (2001) Functional response of the predators Podisus maculiventris (say) and Podisus nigrispinus (Dallas) (Heteroptera: Pentatomidae) to the beet armyworm, Spodoptera exigua (Hubner) (Lepidoptera: Noctuidae): effect of temperature. J Appl Entomol 125:131-134. https://doi.org/10.1046/j1439-0418200100519x

Navarrete B, Carrillo D, Reyes-Martinez AY, Sanchez-Peña S, Lopez-Arroyo J, McAuslane H, Peña JE (2014) Effect of Zelus longipes (Hemiptera: Reduviidae) on Diaphorina citri (Hemiptera: Liviidae) and its parasitoid Tamarixia radiata (Hymenoptera: Eulophidae) under controlled conditions. Fla Entomolo 97: $1537-1543$

Ofuya Tl, Akingbohungbe AE (1988) Functional and numerical responses of Cheilomenes lunata (Fabricius) (Coleoptera: Coccinellidae) feeding on the cowpea aphid, Aphis craccivora Koch (Homoptera: Aphididae). Int J Trop Insect Sci 9:543-546. https://doi.org/10.1017/s1742758400011127

Omkar PA, Pervez A (2004) Functional and numerical responses of Propylea dissecta (Col, Coccinellidae).:140-146 https://doi.org/10.1111/j1439$0418200400824 x$

Parajulee MN, Shrestha RB, Leser JF, Wester DB, Blanco CA (2006) Evaluation of the functional response of selected arthropod predators on bollworm eggs in the laboratory and effect of temperature on their predation efficiency. Environ Entomol 35:379-386. https://doi.org/10.1603/0046-225X-352379

Patel K, Zhang Z (2017) Functional and numerical responses of Amblydromalus limonicus and Neoseiulus cucumeris to eggs and first instar nymph of tomato/ potato psyllid (Bactericera cockerelli). Syst Appl Acarol-UK 22:1476-1488. https://doi.org/10.11158/saa22912

Rahman MM, Islam W, Ahmed KN (2009) Functional response of the predator Xylocoris flavipes to three stored product insect pests. Int J Agric Biol 11:316320

Rahman VJ, Babu A, Roobakkumar A, Perumalsamy K (2012) Functional and numerical responses of the predatory mite, Neoseiulus longispinosus, to the red spider mite, Oligonychus coffeae, infesting tea. J Insect Sci 12:125. https://doi.org/10.1673/03101212501

Sabaghi R, Sahragard A, Hosseini R (2011) Functional and numerical responses of Scymnus syriacus Marseul (Coleoptera: Coccinellidae) to the black bean aphid, Aphis fabae Scopoli (Hemiptera: Aphididae) under laboratory conditions. J Plant Prot Res 51:423-428. https://doi.org/10.2478/v10045-011-0070-4

Sahayaraj K, Kumar V, Avery PB (2015) Functional response of Rhynocoris kumarii (Hemiptera: Reduviidae) to different population densities of Phenacoccus solenopsis (Hemiptera: Pseudococcidae) recorded in the laboratory. Eur. J. Entomol 112:69-74. https://doi.org/10.14411/eje2015020

SAS Institute (2009) Using JMP student edition for Windows and Macintosh: the user's guide to statistics with JMP student edition. SAS institute.

Schäfer K, Goergen G, Borgemeister C (2000) An illustrated identification key to four different species of adult Dinoderus (Coleoptera: Bostrichidae), 
commonly attacking dried cassava chips in West Africa. J Stored Prod Res 36: 245-252. https://doi.org/10.1016/50022-474X(99)00046-6

Sing ES, Arbogast RT (2008) Predatory response of Xylocoris flavipes to bruchid pests of stored food legumes. Entomol Exp Appl 126:107-114. https://doi. org/10.1111/j1570-7458200700647x

Spencer DSC, Ezedinma C (2017) Cassava cultivation in sub-Saharan Africa. In Hershey, C H, McKey, D, Delêtre, M (Eds) Achieving sustainable cultivation of cassava Volume 1: Cultivation techniques (pp 1 -26) Burleigh Dodds Series in Agricultural Science (Book 20), Burleigh Dodds Science Publishing

Ton P, Tovignan S, Vodouhé SD (2000) Endosulfan deaths and poisonings in Benin Pesticides News 47:12-14

Xue Y, Bahlai CA, Frewin A, Sears MK, Schaafsma AW, Hallett RH (2009) Predation by Coccinella septempunctata and Harmonia axyridis (Coleoptera: Coccinellidae) on Aphis glycines (Homoptera: Aphididae). Environ Entomol 38: 708-714. https://doi.org/10.1603/0220380322

\section{Publisher's Note}

Springer Nature remains neutral with regard to jurisdictional claims in published maps and institutional affiliations.

\section{Submit your manuscript to a SpringerOpen ${ }^{\circ}$ journal and benefit from:}

- Convenient online submission

- Rigorous peer review

- Open access: articles freely available online

High visibility within the field

- Retaining the copyright to your article

Submit your next manuscript at $\boldsymbol{\nabla}$ springeropen.com 